\title{
Migration of Hazardous Components of Municipal Landfill Leachates into the Environment
}

\author{
Vasyl Popovych ${ }^{1}$, Jerzy Telak²*, Oksana Telak ${ }^{3}$, Myroslav Malovanyy4, \\ Roman Yakovchuk', Nataliya Popovych ${ }^{5}$
}

1 Department of Ecological Safety, Lviv State University of Life Safety, Kleparivska, 35, 79007, Lviv, Ukraine

2 Academy of Sport Education, ul. Jagiellońska 88, 00-001 Warszawa Poland

3 The Main School of Fire Service in Warsaw, Faculty of Civil Safety Engineering, ul. Słowackiego 52/54, 01-629 Warszawa, Poland

4 Department of Ecology and Sustainable Use of Nature, National University „Lviv Polytechnic”, S. Yura, 3/4, 79013, Lviv, Ukraine

5 Department of Administrative-Legal Disciplines, Lviv State University of Internal Affairs, Gorodotska, 26, 79000, Lviv, Ukraine

* Corresponding author's e-mail: jerzytelak@poczta.onet.pl

\begin{abstract}
The research on the physical and chemical properties of landfill leachates and migration of its hazardous components into hydrosphere and biosphere is a current problem in the global context. The object of the research is landscape-changing factors of the Lviv municipal landfill (Ukraine). It was defined that the largest part of oil products accumulates in the leachates at the south-western side of the landfill $\left(23.6 \mathrm{mg} / \mathrm{dm}^{3}\right)$ and it is 2.36 times higher than the value of the maximum permissible concentration (MPC) $\left(10 \mathrm{mg} / \mathrm{dm}^{3}\right)$; the most saline leachates with chlorides and sulfites are those accumulating at the foot and at the northwestern side; the phosphate content of the investigated leachate samples was the highest at the foot of the landfill and amounted to $12.8 \mathrm{mg} / \mathrm{dm}^{3}$, which exceeds the MPC $\left(10 \mathrm{mg} / \mathrm{dm}^{3}\right)$ by 1.28 times; high concentration of ammonium nitride was discovered in the leachates at the foot $\left(76.1 \mathrm{mg} / \mathrm{dm}^{3}\right)$ and at the northwestern side $\left(46.3 \mathrm{mg} / \mathrm{dm}^{3}\right)$, which exceeds the MPC $\left(30 \mathrm{mg} / \mathrm{dm}^{3}\right)$ by 2.53 and 1.54 times, respectively; the highest indicators of total iron are typical for basins nearby (at the foot $-68.2 \mathrm{mg} / \mathrm{dm}^{3}$, at the northwestern side $-56.3 \mathrm{mg} / \mathrm{dm}^{3}$ ) and exceed the MPC norms $\left(2.5 \mathrm{mg} / \mathrm{dm}^{3}\right) \mathrm{by}$ 27.28 and 22.52 times, respectively. According to certain indicators, the content of hazardous components in the leachates, which accumulate at the foot and at the northwestern side, exceeds the MPC and is several times higher than in the natural basins at the distance of 800 and $1200 \mathrm{~m}$.
\end{abstract}

Keywords: hydrosphere, physical and chemical properties of leachates, water pollution, municipal solid waste.

\section{INTRODUCTION}

Landfills are objects with increased ecological and technological hazard. A number of scientific studies have defined three main hazardous factors of landfills: biogas generation, waste combustion and leachate drainage. In particular, the research by Vodyanitskii (2016) stresses the fact that municipal solid waste landfill is one of the largest sources of environmental pollution, where leachate percolates through soil, reaches surface and ground waters. Increased radiation background is observed at the landfills (Tulaydan et al., 2017; Popovych et al., 2018; Malovanyy et al., 2018). The work of Fytanidis, Voudrias (2014) is dedicated to the modeling of unsaturated polyphase airflows and liquid phases and biochemical processes of aerobic biodegradation of organic fraction of municipal solid waste, taking into account their temporal and spatial evolution. 
The scientists in Poland searched for the methods of leachate filtration from municipal solid waste landfill (Suchecka et al., 2006). The results of the research on the influence of municipal landfill age on the qualitative changes of leachates based on 4 years monitoring of the leachate at the landfill of Wysieka near Bartoszyce (Poland) were described in the work. It was found that the fluctuation of the content of such indicators as phosphorus, chlorides, calcium, magnesium, sulfate, dissolved solid solutions, and heavy metals depends on a season of a year (seasonal variations), rather than on the age of landfill (Kulikowska, Klimiuk, 2008).

A critical analysis of landfill leachates treatment processes and their influence on aquifers is described in the work of (Christensen et al., 2001). Mor et al. (2006) took the samples of leachates and groundwater at the Ghazipur landfill (India) and its surrounding area in order to study the possible leachate effect on the quality of groundwater.

In order to assess the land reclamation feasibility of municipal solid waste landfills, characteristics, distribution and mobility of heavy metals in the landfill (Xiaoli et al., 2007) were examined. It was defined that relatively high levels of heavy metals accumulate in the landfill. Renou et al. (2008) report that the use of membrane technologies, especially reverse osmosis, is an indispensable method of landfill leachate treatment. It was defined that the Fenton's method is an essential and competitive technology for purification or pre-treatment of landfill leachates in bench-, pilot- and full-scale studies (Deng, Englehardt, 2006). It was also defined that the landfill leachate can be successfully purified with the use of peat, by eliminating $100 \%$ hazardous substances and ammonium (Heavey, 2003). The work of Uygur,
Kargi (2004) was dedicated to the investigation on the biological purification of landfill leachates. It was found that adding municipal wastewater and powdered activated carbon to the pre-treated leachate improved the elimination of nutrients during five-step purification.

Thereby, the research on the physical and chemical properties of landfill leachate and migration of its hazardous components into hydrosphere and biosphere is a current issue in the global context for today.

\section{MATERIALS AND METHODS}

The object of the research involves the landscape-transforming factors of the Lviv municipal landfill. The subject of the research pertains to the hazardous components of landscape leachates and their migration into the environment. The following research methods were used in the work: quantitative and qualitative ecology, soil science, chemical, physical, mathematical and statistical, and systemic analysis.

In order to define the interdependence between the physical and chemical indicators of the basins with the leachate, the Pearson correlation coefficient was used.

The sampling for the research on the toxicity of the filtration basins of the Lviv municipal landfill was carried out on four plots of man-made and natural origin (Fig. 1): 1- artificial filtration lake at the foot of the landfill; 2 - artificial filtration lake at the northwestern side of the landfill (440 $\mathrm{m}$ of the foot to the north east); man-made basin at the distance of $800 \mathrm{~m}$ to the east of the foot of the landfill; 4 - natural basin at $1260 \mathrm{~m}$ to the east of the foot of the landfill.

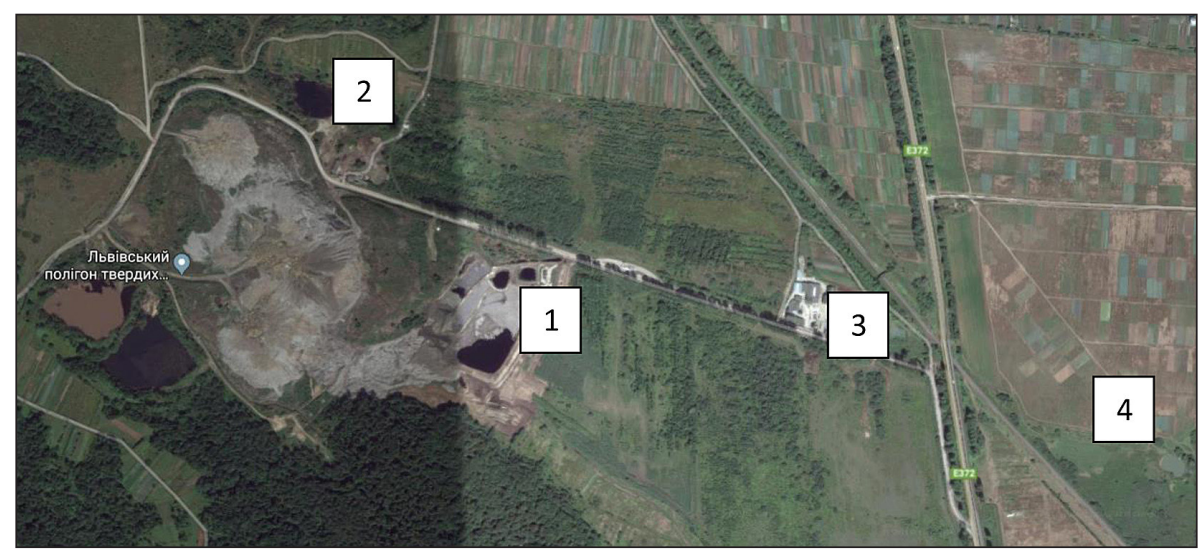

Fig. 1. Plots for water sampling 
The samples were selected based on the recommendations, which are indicated in the regulatory documentation (LGD, 1994'). The selected samples were characterized with the following indicators (parameters):

- Organoleptic: color, transparency, smell - according to the handbook (Lurie, 1984);

- Physical: suspended matters, dry residue, mineral residue - gravimetrical methods (measuring devices - analytical balance, laboratory thermometers) [LGD, 1994²; LGD, 1995'];

- Physical and chemical: pH indicator, general mineralization - potentiometrical methods according to the instruction manuals for relative equipment (device - „pH-150MI” pH-meter, TDS multi-purpose salt meter);

- Chemical: permanent hardness, alkalinity (carbonate hardness), bicarbonate content - titrimetric methods with Trilon B and hydrochloric acid, respectively (Lurie, 1984; Dmitriev et al., 1989) chloride content - titrimetric method with silver nitrate (Lurie, 1984); sulfites content - gravimetric method (for instance, analytic balance) (Lurie, 1984); nitrites content - photometrical method with the Griess reagent (for instance, electrophotocolorimeter KFK-2) (LGD, 1995²); nitrates content - photometric method with the Griess salicylic acid (for example, KFK-2 electrophotocolorimeter) (LGD, 19953); ammonium ion content - photometric method with the Nesler Griess reagent (for example, KFK-2 electrophotocolorimeter) (LGD, 1995); iron content - photometric method with rhodanide (for example, KFK-2 electrophotocolorimeter) $\left(\mathrm{LGD}, 1995^{5}\right)$; chemical oxygen demand (COD) - titrimetric method with potassium dichromate (Lurie, 1984); oil products content - gravimetric method with chloroform and hexane (for instance, analytical balance) (WDS, 2003).

\section{RESULTS AND DISCUSSION}

The Lviv municipal landfill is one of the largest in Ukraine, which accumulated waste from the territory with over 1 million residents for 60 years. It is located at $3 \mathrm{~km}$ of the northern boundary of Lviv. The landfill was used since 1957 until 2016. During the exploitation period, around 55 million $\mathrm{m}^{3}$ of waste was accumulated there. Until 1990, not only solid waste was stored, but also toxic industrial waste. Its amount reaches 2 million tons. Besides garbage, over 200 thousand tons of acid oil tar, which is waste of the „Lvivsky doslidnyy naftomaslozavod" open joint-stock company („Lviv research oil and lubricant plant” (Voloshyn, 2012). Total area of basins with oil tar is approximately 5 ha; they accumulated around 250 thousand $\mathrm{m}^{3}$ of oil processing wastes, which contain sulfuric acid and 60 thousand $\mathrm{m}^{3}$ of acid water (Haydin et al., 2013). Every day, 70 to $300 \mathrm{~m}^{3}$ of leachate is generated in the body of the Lviv landfill MSW with a tendency to increase annually.

On May 29, 2016, the 2,000- $\mathrm{m}^{2}$ area of the Lviv municipal landfill was on fire. On May 30, 2016, soon after the fire suppression, a landslide occurred from the height of $90 \mathrm{~m}$ with the total landslide area of 30 thousand $\mathrm{m}^{2}$ and volume of approximately 100 thousand $\mathrm{m}^{3}$, covering 3 rescuers and employees of „Zbyranka” municipal enterprise, which manages the landfill exploitation. During the search and rescue activities, the banks of protective levees of leachate accumulating basins were strengthened (4,544 sandbags were put and about $73,000 \mathrm{~m}^{3}$ of soil was poured). On May 31, 2016, three rescuers' bodies were found. The search activities of municipal enterprise employee continued, but they turned out to be unsuccessful (Hlobenko, 2016).

A number of scientific works is dedicated to the research of hazardous factors of the Lviv municipal landfill, in particular leachates. For example, the heavy metal content in leachate is detected by the presence of metal-containing waste in the trash body, which can be corrodible, takes part in oxidation-reduction reactions, as well as undergoes sorption and desorption (Haydin et al., 2013).

According to the scientific research (Voloshyn, 2012), the leachate accumulating at the foot of the landfill is an aqueous solution of a complex chemical content, which determines the ecological condition of surface and ground waters. Its color is dark black, it has a sharp, pungent odour, a great number $\left(6-8 \mathrm{mg} / \mathrm{dm}^{3}\right)$ of suspended matters, extremely high organic content (biochemical oxygen demand, BOD $\left.7,840 \mathrm{mg} / \mathrm{dm}^{3}\right)$, nitrites $\left(10,583 \mathrm{mg} / \mathrm{dm}^{3}\right)$, chlorine $\left(5,000-8,000 \mathrm{mg} / \mathrm{dm}^{3}\right)$, high concentration of a range of heavy metals: lead (MPC 55), cadmium (38 MPC), manganese (3 MPC), chromium (2.4 MPC) and many others (Voloshyn, 2012). 
It was defined that the leachate of the Lviv landfill is characterized with the high content of organic matters - above $12.8 \mathrm{~g} / \mathrm{l}$, sodium chloride (around $9 \mathrm{~g} / \mathrm{l}$ ), COD, BOD, and high level of heavy metals. The leachate disposal into municipal pollution control facilities is impossible without specialized pre-treatment (Haydin et al., 2013).

All the above-mentioned studies are definitely relevant, although the physical and chemical properties of leachates change with the passage of time. In this regard, a constant landfill monitoring is essential.

After the analysis of odour, transparency, $\mathrm{pH}$ and oil products content, it was defined that the land plots 1 and 2 were characterized with the indicators, which differ essentially from those in the basins at the distance of $800 \mathrm{~m}$ and $1260 \mathrm{~m}$ of the foot (Fig. 2).

The value of odour at $+20^{\circ} \mathrm{C}$ is the highest for the leachate accumulating at the foot of the landfill ( 2 points) and it decreases with the distance to 0.5 point. The transparency of the leachate is the lowest at the foot and it is just $4 \mathrm{~cm}$. At the northwestern side of the landfill, the transparency of the leachate is $12 \mathrm{~cm}$, which is a significantly low indicator, as well as for the foot. At the distance of $800 \mathrm{~m}$ and $1260 \mathrm{~m}$ of the landfill foot, water transparency in the ponds is $28 \mathrm{~cm}$ and $31 \mathrm{~cm}$, respectively. The leachates at the northwestern side of the landfill are acidic ( $\mathrm{pH}$ is 2.1). The value of leachate $\mathrm{pH}$ becomes alkaline (8.1) at the foot and it is caused by the deposition of washed nutrients from the landfill body. At the distance of more than $800 \mathrm{~m}$ of the landfill foot, the water $\mathrm{pH}$ in the ponds slightly decreases and it reaches 7.2-7.6. The greatest amount of oil products accumulates in the leachates at the southwestern side of the landfill $\left(23.6 \mathrm{mg} / \mathrm{dm}^{3}\right)$ and exceeds the MPC by 2.36 times $\left(10 \mathrm{mg} / \mathrm{dm}^{3}\right)$. The oil products content at the foot is $1.69 \mathrm{mg} / \mathrm{dm}^{3}$ and it is within the MPC norms. The oil products content in the basins at the distance of $800 \mathrm{~m}$ and more is $0.28-0.43 \mathrm{mg} / \mathrm{dm}^{3}$. The dynamics of oil products distribution is shown in Figure 3.

The analysis of the landfill leachates salinity with chlorides and sulfites showed that the
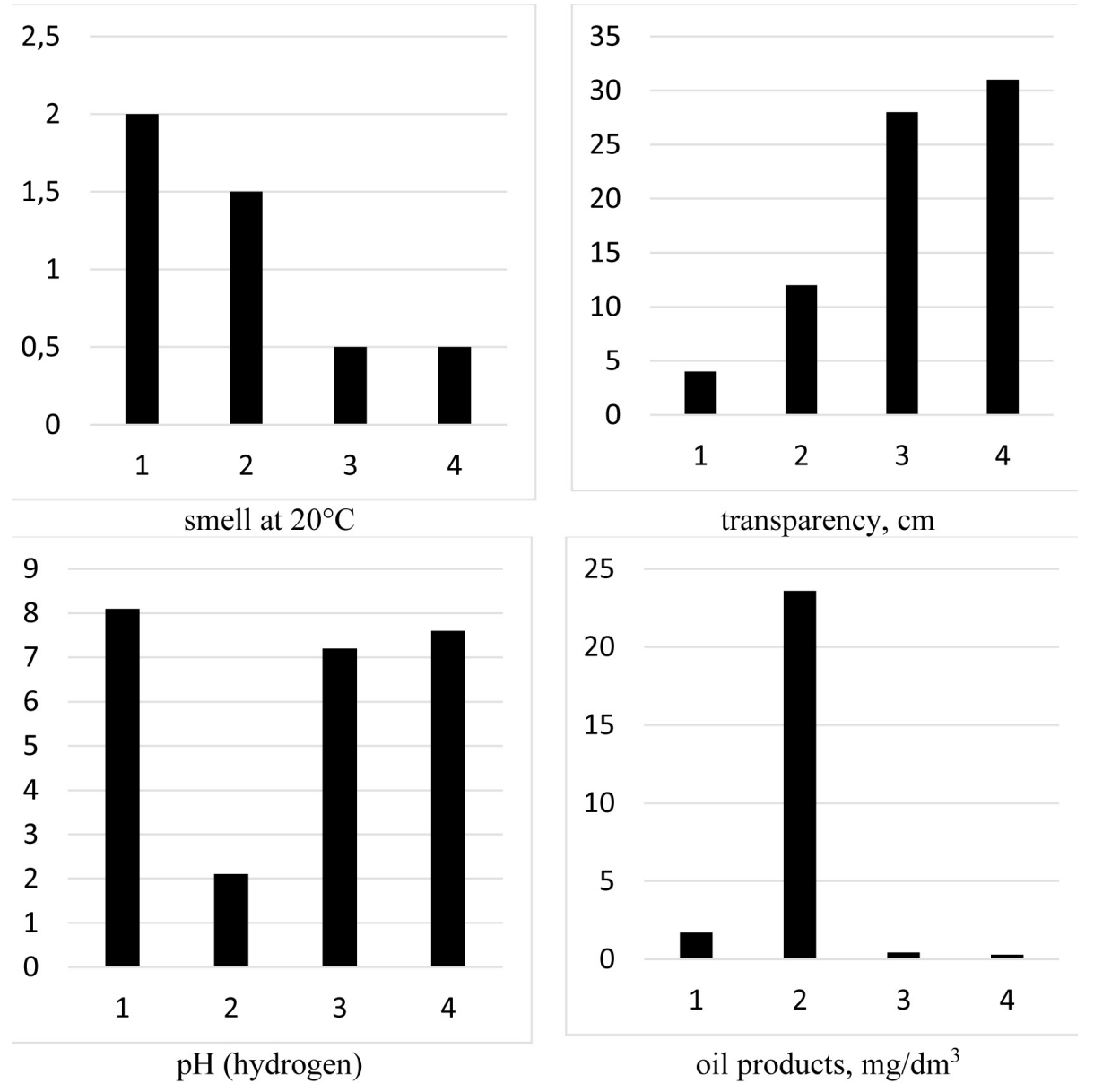

Fig. 2. The values of odour, transparency, $\mathrm{pH}$ and oil products in the leachates of the Lviv municipal landfill: 1 - Leachate at the foot, 2 - Leachate at the n-w side, 3 - Basin at $800 \mathrm{~m}, 4$ - Pond at 1,260 m 


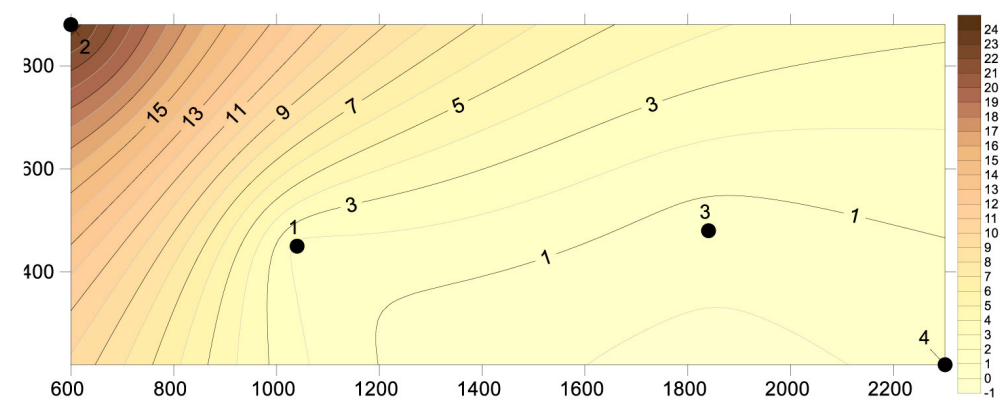

Fig. 3. The dynamics of oil products distribution in the zone of influence of the Lviv landfill $\left(\mathrm{mg} / \mathrm{dm}^{3}\right)$

most saline filtration basins are the plots at the foot and at the northwestern side. The highest chloride content in the leachate was observed at the foot $-2045 \mathrm{mg} / \mathrm{dm}^{3}$, which exceeds MPC $\left(350 \mathrm{mg} / \mathrm{dm}^{3}\right)$ by 5.84 times. The chloride content was $774 \mathrm{mg} / \mathrm{dm}^{3}$ at the northwestern side of the landfill, which exceeds the MPC by 2.21 times. The highest sulfite content in the leachate was found at the northwestern side and it was $3,716 \mathrm{mg} / \mathrm{dm}^{3}$, which exceeds the MPC $\left(500 \mathrm{mg} / \mathrm{dm}^{3}\right)$ by 7.43 times. The sulfites content was $1,108 \mathrm{mg} / \mathrm{dm}^{3}$ at the foot, which exceeds the MPC by 2.21 times. Sulfites content was within the MPC norms in other basins (Fig. 4).

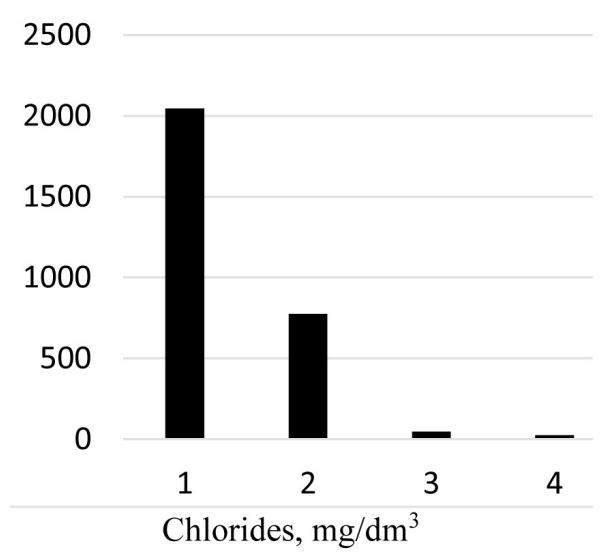

Migration of chlorides and sulfites into the environment is described in Fig. 5 and Fig. 6.

The analysis of the research results regarding nitrates, nitrites and ammonium content showed that the excess of these substances is typical for the leachates accumulating at the foot and at the northwestern side of the Lviv municipal landfill (Fig. 7).

The highest level of nitrates is detected in the leachates at the foot of the landfill $\left(158.3 \mathrm{mg} / \mathrm{dm}^{3}\right)$, which exceeds the MPC $\left(45 \mathrm{mg} / \mathrm{dm}^{3}\right)$ by 3.52 times. The nitrate content $\left(86.3 \mathrm{mg} / \mathrm{dm}^{3}\right)$ exceeds the MPC by 1.92 times at the northwestern side. The nitrate content in all

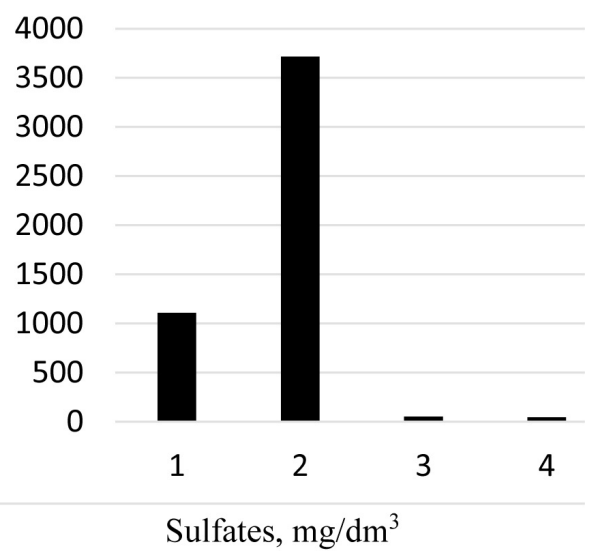

Fig. 4. The values of chloride and sulfite content in the leachate of the Lviv municipal landfill: 1 - leachate at the foot; 2 - leachate at the N-W side; 3 - basin at $800 \mathrm{~m} ; 4$ - pond at $1,260 \mathrm{~m}$

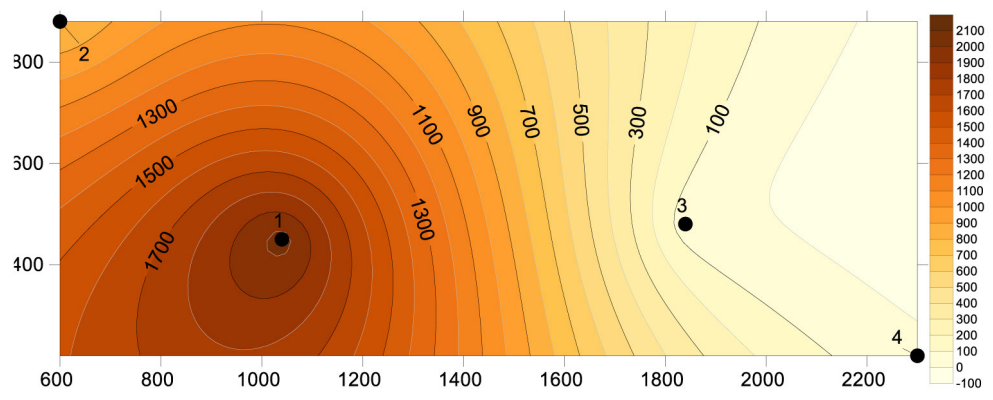

Fig. 5. Dynamics of chlorides $\left(\mathrm{Cl}^{-}\right)$migration in the filtration and natural basins of the Lviv landfill $\left(\mathrm{mg} / \mathrm{dm}^{3}\right)$ 


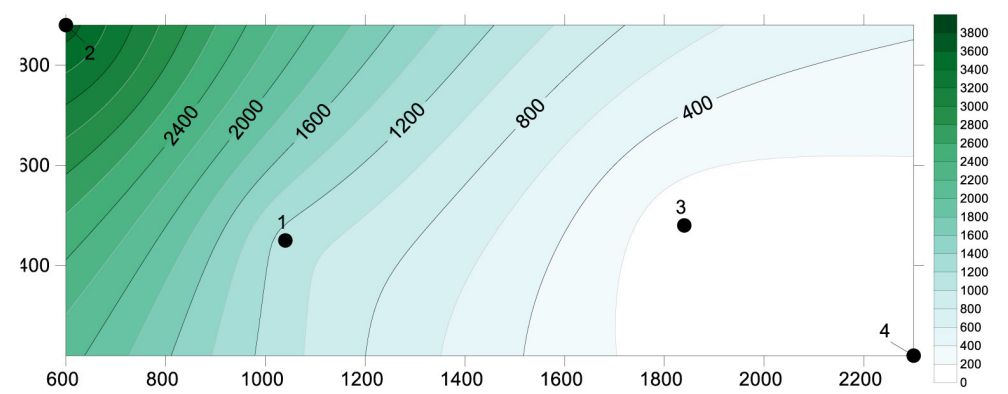

Fig. 6. Dynamics of sulfites $\left(\mathrm{SO}_{4}^{2-}\right)$ distribution in the filtration and natural basins of the Lviv landfill $\left(\mathrm{mg} / \mathrm{dm}^{3}\right)$

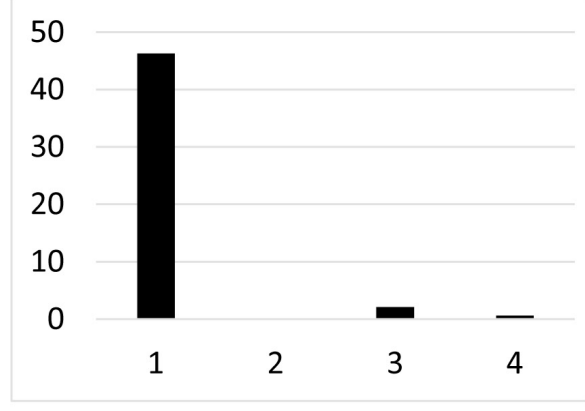

Nitrites, $\mathrm{mg} / \mathrm{dm}^{3}$

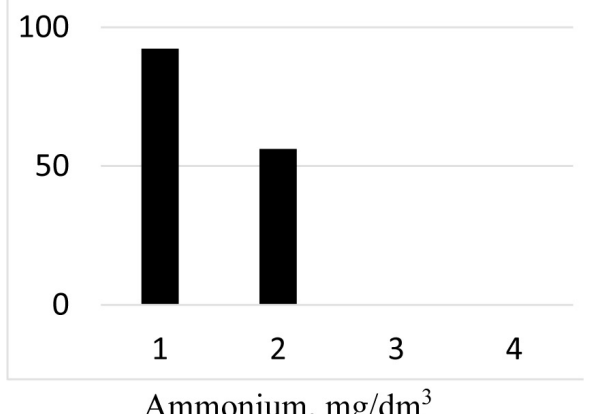

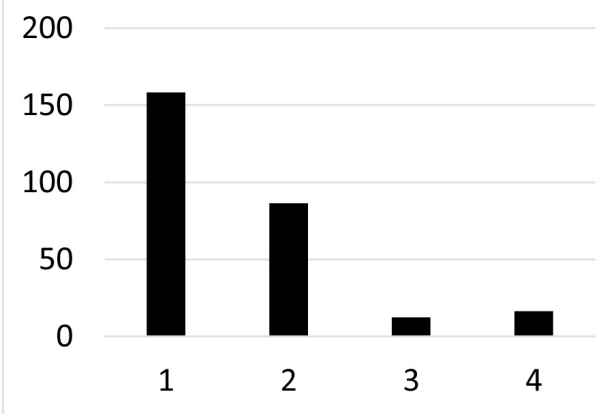

Nitrates, $\mathrm{mg} / \mathrm{dm}^{3}$

Fig. 7. The values of nitrates, nitrites and ammonium content in the leachates of the Lviv municipal landfill: 1 - leachate at the foot; 2 - leachate at the $\mathrm{n}$-w side; 3 - basin at $800 \mathrm{~m} ; 4$ - pond at $1,260 \mathrm{~m}$

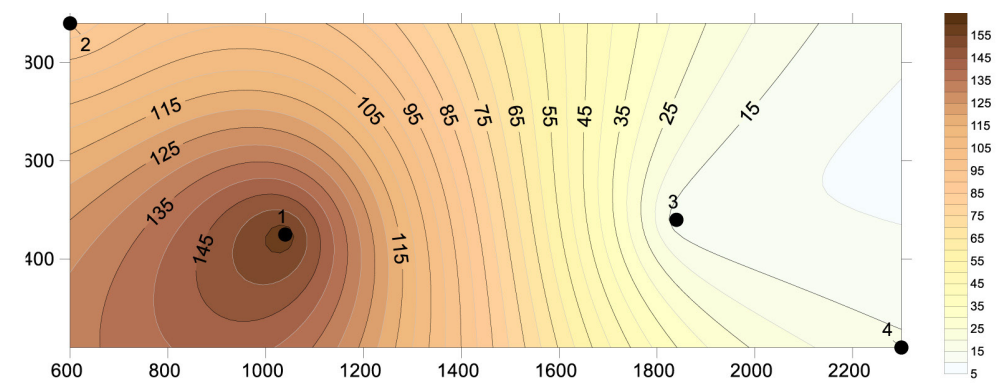

Fig. 8. The dynamics of nitrate $\left(\mathrm{NO}_{3}^{-}\right)$distribution in the filtration and natural basins of the Lviv landfill $\left(\mathrm{mg} / \mathrm{dm}^{3}\right)$

other basins was within the MPC norms and it was $12.3-16.2 \mathrm{mg} / \mathrm{dm}^{3}$. The highest nitrite content was also observed in the leachates at the foot of the landfill $\left(46.3 \mathrm{mg} / \mathrm{dm}^{3}\right)$, which exceeds the MPC $\left(3.3 \mathrm{mg} / \mathrm{dm}^{3}\right)$ by 14 times. The ammonium content in the leachates at the foot $\left(92.3 \mathrm{mg} / \mathrm{dm}^{3}\right)$ and at the northwestern side $\left(56.2 \mathrm{mg} / \mathrm{dm}^{3}\right)$ of the landfill exceeds the MPC $\left(38 \mathrm{mg} / \mathrm{dm}^{3}\right)$ by 2.43 and 1.48 times, respectively. The ammonium content in all other basins was $0.11-0.18 \mathrm{mg} / \mathrm{dm}^{3}$ and did not exceed the MPC norms. The distribution of nitrates and nitrites in the zone of influence of the Lviv landfill is shown in the Figure 8 and Figure 9. 
The phosphate content in the investigated samples of the leachates was the highest at the foot and it was $12.8 \mathrm{mg} / \mathrm{dm}^{3}$, which exceeds the MPC $\left(10 \mathrm{mg} / \mathrm{dm}^{3}\right)$ by 1.28 times (Fig. 10).

The phosphate content in the leachates accumulating at the northwestern side of the landfill was $3.6 \mathrm{mg} / \mathrm{dm}^{3}$. A high concentration of hydrogen nitride was observed in the leachates at the foot $\left(76.1 \mathrm{mg} / \mathrm{dm}^{3}\right)$ and at the northwestern side $\left(46.3 \mathrm{mg} / \mathrm{dm}^{3}\right)$ which exceeds the MPC $\left(30 \mathrm{mg} / \mathrm{dm}^{3}\right)$ by 2.53 and 1.54 times, respectively. The hydrogen nitride content in all the other investigated basins was $0.09-0.16 \mathrm{mg} / \mathrm{dm}^{3}$ and within the permissible norms. The highest indicators of total iron content are typical for the basins located in the nearest surroundings of the landfill (at the foot $-68.2 \mathrm{mg} / \mathrm{dm}^{3}$, at the northwestern side $-56.3 \mathrm{mg} / \mathrm{dm}^{3}$ ) and exceed the permissible norms $\left(2.5 \mathrm{mg} / \mathrm{dm}^{3}\right)$ by 27.28 and 22.52 times, accordingly. The total iron content in all the other basins was $0.18-0.21 \mathrm{mg} / \mathrm{dm}^{3}$ and within the permissible norms.

The migration of total iron into the environment is shown in Figure 11.

Chemical oxygen demand (COD) values in the filtration basins at the foot of the landfill and at

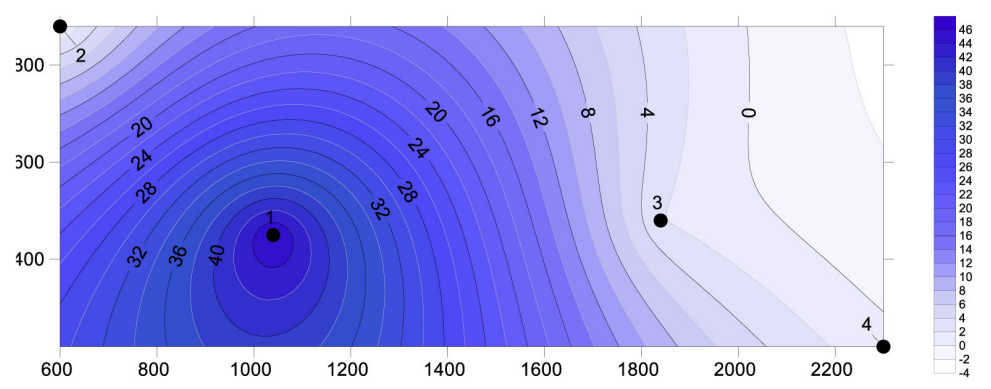

Fig. 9. The dynamics of nitrite $\left(\mathrm{NO}_{2}^{-}\right)$distribution in the filtration and natural basins of the Lviv landfill $\left(\mathrm{mg} / \mathrm{dm}^{3}\right)$
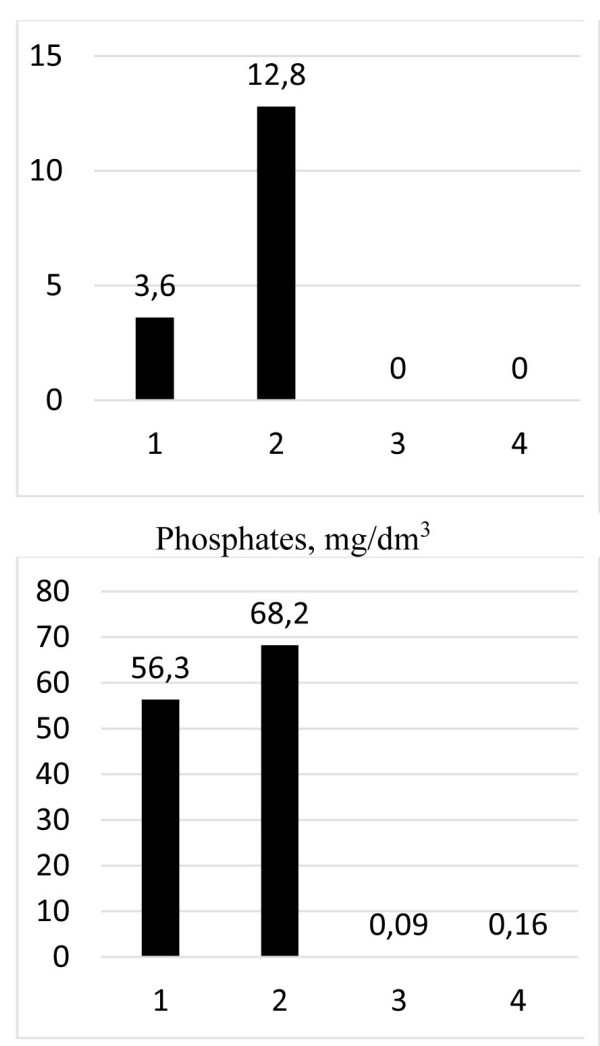

Total iron, $\mathrm{mg} / \mathrm{dm}^{3}$

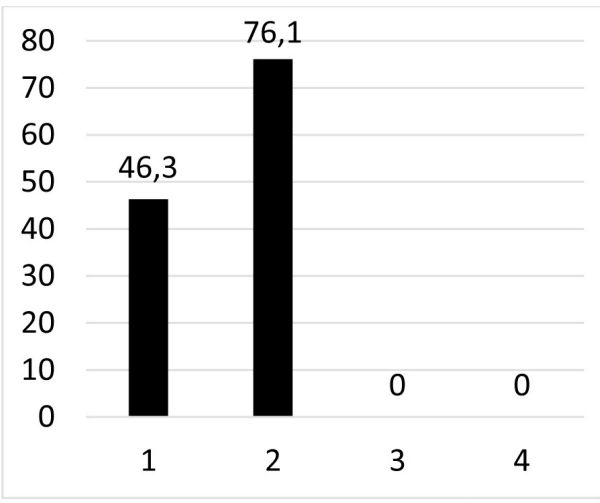

Hydrogen nitride, $\mathrm{mg} / \mathrm{dm}^{3}$

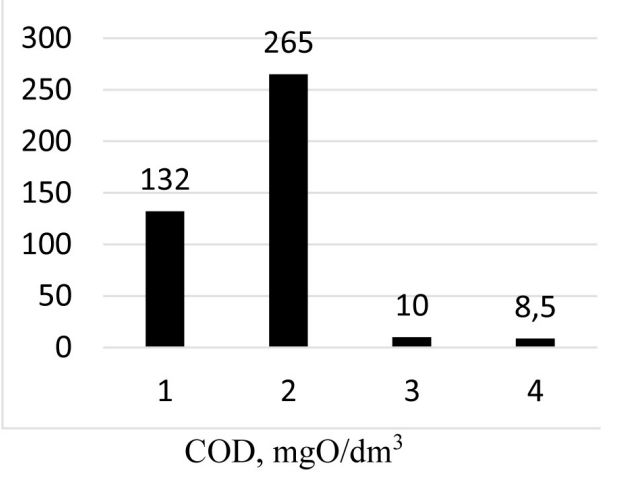

Fig. 10. The values of phosphates, hydrogen nitride, iron content and chemical oxygen demand in the leachates of the Lviv municipal landfill: 1 - leachate at the foot; 2 - leachate at the NW side; 3 - basin at $800 \mathrm{~m}$; 4 - pond at $1,260 \mathrm{~m}$. 
its northwestern side are high $\left(265 \mathrm{mgO} / \mathrm{dm}^{3}\right.$ and $132 \mathrm{mgO} / \mathrm{dm}^{3}$, respectively) and its concentration is permissible $\left(810 \mathrm{mgO} / \mathrm{dm}^{3}\right)$. COD content in all the other basins was $8.5-10.8 \mathrm{mgO} / \mathrm{dm}^{3}$.

The higher value of suspended matters content is typical for filtration basins in the nearest surroundings of the landfill (at the foot $-46.2 \mathrm{mg} / \mathrm{dm}^{3}$, at the northwestern side $54.8 \mathrm{mg} / \mathrm{dm}^{3}$ ) comparing to all the other plots (at the distance of $800 \mathrm{~m}-42.1 \mathrm{mg} / \mathrm{dm}^{3}$, at $1260 \mathrm{~m}-$ $12.8 \mathrm{mg} / \mathrm{dm}^{3}$ ). The highest carbonate hardness of the leachates is representative also at the foot of the landfill $-21.6 \mathrm{mg} / \mathrm{dm}^{3}$, the lowest - at $1260 \mathrm{~m}$ of the foot of the landfill $\left(6.7 \mathrm{mg} / \mathrm{dm}^{3}\right)$ (Fig. 12).

After heating to a temperature of $90^{\circ} \mathrm{C}$, the highest values of the dry residue $\left(11,554 \mathrm{mg} / \mathrm{dm}^{3}\right)$ are observed in the leachates selected from the basin at the foot of the landfill, which exceeds the MPC $\left(1,000 \mathrm{mg} / \mathrm{dm}^{3}\right)$ by more than 11.5 times (Fig. 13).

The value of dry residue at the northwestern side exceeds - MPC by 7.13 times. At the distance of $800 \mathrm{~m}$ and $1260 \mathrm{~m}$ of the foot of the landfill, the value of dry residue almost reaches the permissible norms $\left(874 \mathrm{mg} / \mathrm{dm}^{3}\right.$ and $714 \mathrm{mg} / \mathrm{dm}^{3}$, respectively). After heating to $800^{\circ} \mathrm{C}$, the highest values of mineral residue $\left(7,320 \mathrm{mg} / \mathrm{dm}^{3}\right)$ were observed in the leachates sampled from the basins located at the foot of the landfill. The value of mineral residue at the northwestern side is $6,180 \mathrm{mg} / \mathrm{dm}^{3}$. The value of mineral residue at the distance of $800 \mathrm{~m}$ and $1260 \mathrm{~m}$ of the foot of the landfill is 10 times lower than on all the other plots (628 mg/dm ${ }^{3}$ and $597 \mathrm{mg} / \mathrm{dm}^{3}$, accordingly). The highest carbonate content $\left(1,318 \mathrm{mg} / \mathrm{dm}^{3}\right)$ was

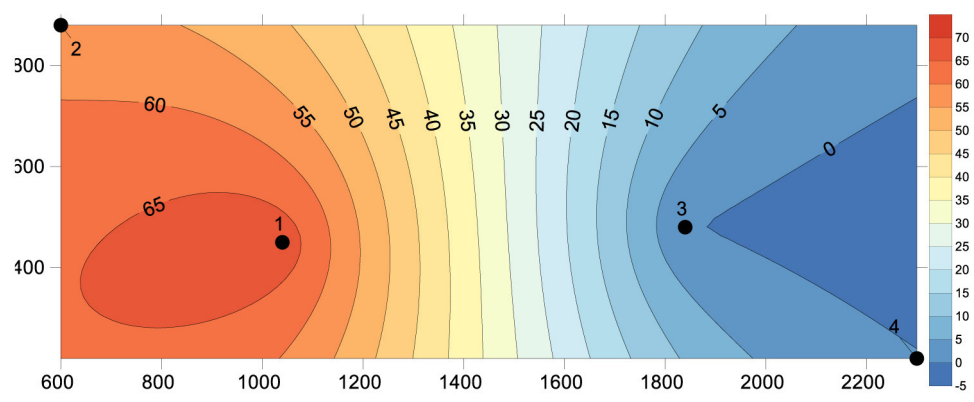

Fig. 11. Dynamics of total iron distribution $\left(\mathrm{Fe}_{\text {total }}\right)$ in the filtration and natural basins of the Lviv landfill $\left(\mathrm{mg} / \mathrm{dm}^{3}\right)$

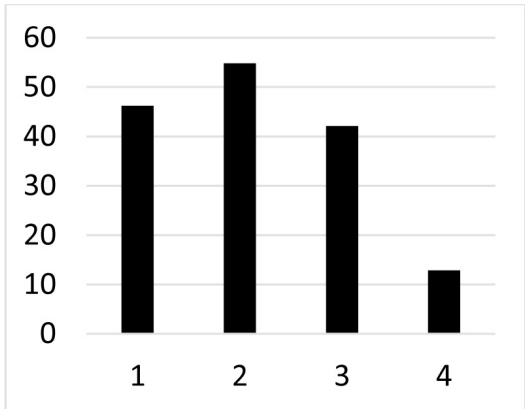

Suspended matters, $\mathrm{mg} / \mathrm{dm}^{3}$

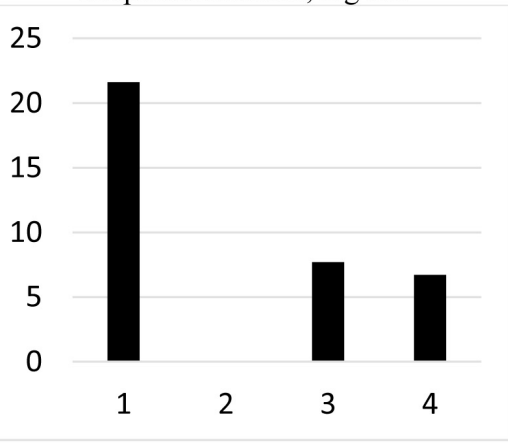

Carbonate hardness, $\mathrm{mg}$ - equivalent $/ \mathrm{dm}^{3}$

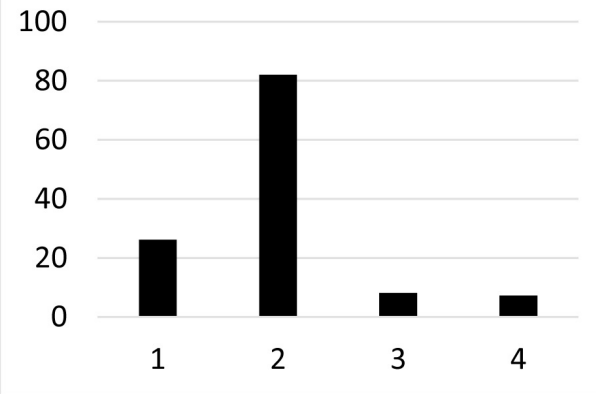

Total hardness, mg- equivalent $/ \mathrm{dm}^{3}$

Fig. 12. The value of suspended matters, general and carbonate hardness in the leachates of the Lviv municipal landfill: 1 - leachate at the foot; 2 - leachate at the n-w side; 3 - basin at $800 \mathrm{~m} ; 4$ - pond at 1,260 m 

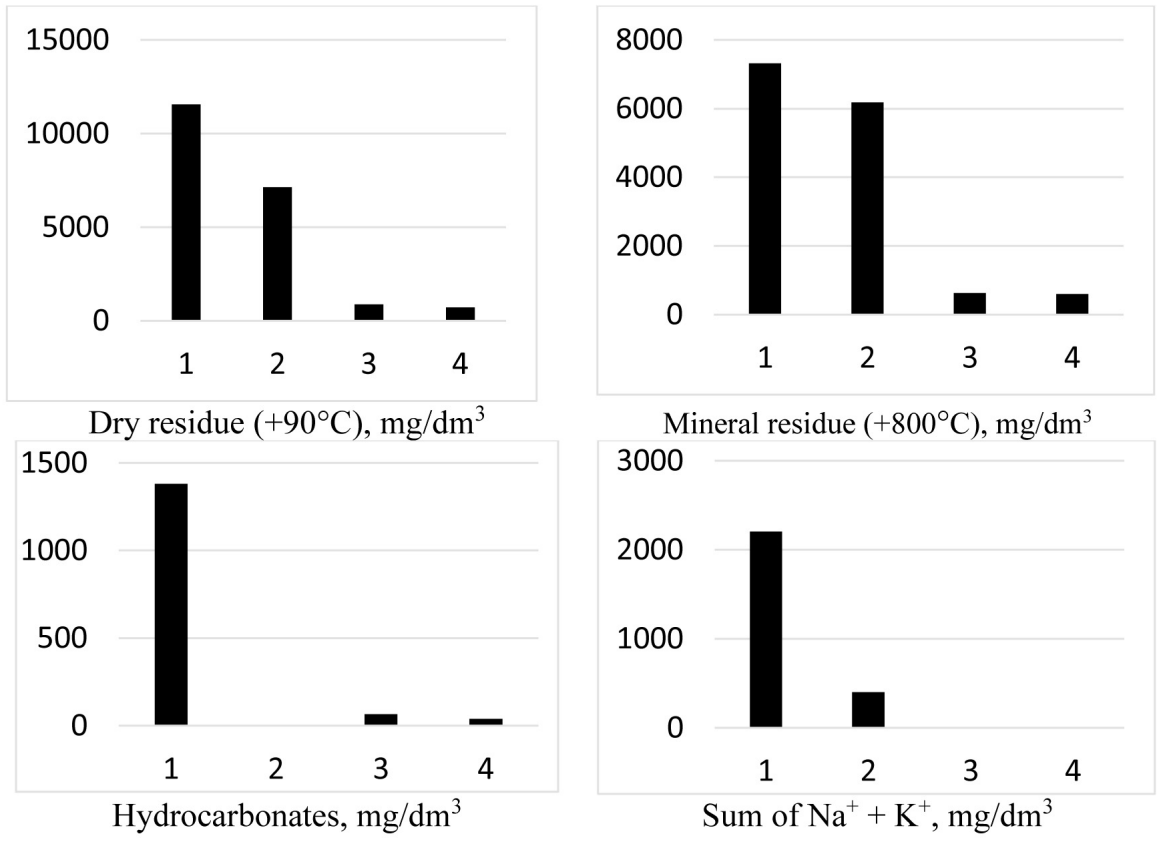

Fig. 13. The values of dry and mineral residues, hydrocarbonates and $\mathrm{Na}^{+}+\mathrm{K}^{+}$content in the leachates of the Lviv municipal landfill: 1 - Leachate of the foot, 2 - Leachate at the N-W side; 3 - Basin at 800 m; 4 - Pond at $1,260 \mathrm{~m}$

detected in the leachates sampled from the basin at the foot of the landfill. The value of hydrocarbonates at the distance of $800 \mathrm{~m}$ and $1260 \mathrm{~m}$ of the foot of the landfill is more than 3 times lower than on all the other plots $\left(470 \mathrm{mg} / \mathrm{dm}^{3}\right.$ and $409 \mathrm{mg} / \mathrm{dm}^{3}$, respectively). It was found that the sum of the $\mathrm{Na}^{+}+\mathrm{K}^{+}$content in the leachates at the foot of the landfill was $2,203 \mathrm{mg} / \mathrm{dm}^{3}$, at the northwestern side $-400 \mathrm{mg} / \mathrm{dm}^{3}$, at the distance of $800 \mathrm{~m}$ and $1260 \mathrm{~m}$ of the foot $-64.7 \mathrm{mg} / \mathrm{dm}^{3}$ and $38.7 \mathrm{mg} / \mathrm{dm}^{3}$, respectively.

In view of the above-mentioned research, it is clear that the most polluted leachates of the landfill are those accumulating at the foot of the landfill and at the northwestern side. At the distance of $800 \mathrm{~m}$ and 1,260 m, the concentration of the pollutants decreases substantially; however, some of them exceed the permissible norms and put a considerable pressure on the environment. It was defined that the set of indicators of each basin with the leachates correlate between each other.
The physical and chemical properties of the leachate indicators located at the foot and at the northwestern side are subject to change, similarly to the indicators of the basins at the distance of $800 \mathrm{~m}$ and $1,260 \mathrm{~m}$ of the foot of the landfill (correlation coefficient is strong, positive $r>0.83$ ) (Table 1).

\section{CONCLUSIONS}

It was found that the hazardous components accumulating in the filtration basins at the foot have a direct influence on the natural basins at the distance of $800 \mathrm{~m}$ and $1,260 \mathrm{~m}$ of the foot of the landfill (correlation coefficient for all set of data $r>0,83)$. According to certain indicators, the hazardous components content in the leachates accumulating at the foot and at the northwestern side exceeds the maximum permissible concentration and is several times higher than indicators in the natural basins at the distance of $800 \mathrm{~m}$ and $1,260 \mathrm{~m}$ :

Table 1. Correlation coefficient between the indicators of the filtration basins

\begin{tabular}{|c|c|c|c|c|}
\hline Specification & Leachate N-W side & Leachate of the foot & Basin at $800 \mathrm{~m}$ & Pond at $1260 \mathrm{~m}$ \\
\hline Leachate $\mathrm{N}-\mathrm{W}$ side & 1 & & & \\
\hline Leachate of the foot & 0,92084027 & 1 & & \\
\hline Basin at $800 \mathrm{~m}$ & 0,834774208 & 0,924641864 & 1 & 1 \\
\hline Pond at $1260 \mathrm{~m}$ & 0,837134897 & 0,912402849 & 0,99661632 & \\
\hline
\end{tabular}


- the leachate transparency is the lowest at the foot and it is just $4 \mathrm{~cm}$. At the northwestern side of the landfill, the leachate transparency is $12 \mathrm{~cm}$, which is an extremely low indicator, as well as for the foot. The water transparency in the ponds at the distance of $800 \mathrm{~m}$ and $1,260 \mathrm{~m}$ is $28 \mathrm{~cm}$ and $31 \mathrm{~cm}$, accordingly;

- the greatest amount of oil products accumulates in the leachate at the northwestern side of the landfill $\left(23.6 \mathrm{mg} / \mathrm{dm}^{3}\right)$ and exceeds the value of MPC $\left(10 \mathrm{mg} / \mathrm{dm}^{3}\right)$ by 2.36 times;

- the highest chloride and sulfate content was observed in the leachates accumulating at the foot and at the northwestern side;

- the analysis of the research results regarding nitrates, nitrites and ammonium showed that the excess of these matters is representative for the leachates accumulating at the foot and at the northwestern side;

- the highest phosphates content in the investigated samples of the leachates was at the foot of the landfill and it was $12.8 \mathrm{mg} / \mathrm{dm}^{3}$, which exceeds the MPC $\left(10 \mathrm{mg} / \mathrm{dm}^{3}\right)$ by 1.28 times;

- high concentration of nitrogen hydride was found in the leachates at the foot $\left(76.1 \mathrm{mg} / \mathrm{dm}^{3}\right)$ and at the northwestern side $\left(46.3 \mathrm{mg} / \mathrm{dm}^{3}\right)$, which exceeds the MPC $\left(30 \mathrm{mg} / \mathrm{dm}^{3}\right)$ by 2.53 and 1.54 times, accordingly;

- regarding the total iron content in the leachates, its highest indicators are also typical for the basins located in the nearest surroundings of the landfill (at the foot $-68.2 \mathrm{mg} / \mathrm{dm}^{3}$, at the northwestern side $-56.3 \mathrm{mg} / \mathrm{dm}^{3}$ ) and exceed the MPC norms $\left(2.5 \mathrm{mg} / \mathrm{dm}^{3}\right)$ by 27.28 and 22.52 , respectively;

- after heating to $90^{\circ} \mathrm{C}$, the highest dry residue indicators $\left(11,554 \mathrm{mg} / \mathrm{dm}^{3}\right)$ were observed in the leachate samples from the basins located at the foot of the landfill, which exceed the MPC $\left(1,000 \mathrm{mg} / \mathrm{dm}^{3}\right)$ by more than 11.5 times;

- after heating to $800^{\circ} \mathrm{C}$, the highest values of mineral residue $\left(7,320 \mathrm{mg} / \mathrm{dm}^{3}\right)$ were found in the leachate samples from the basins located at the foot of the landfill. The value of the dry residue at the northwestern side was $6,180 \mathrm{mg} / \mathrm{dm}^{3}$. At the distance of $800 \mathrm{~m}$ and $1,260 \mathrm{~m}$ of the foot of the landfill, the value of the dry residue was 10 times lower than on all the other plots $\left(628 \mathrm{mg} / \mathrm{dm}^{3}\right.$ and $597 \mathrm{mg} / \mathrm{dm}^{3}$, respectively).

According to the results of our research, the leachates accumulating at the foot of the landfill cause the most ecological and technological hazard to biota.

\section{REFERENCES}

1. Christensen T. H., Kjeldsen P., Bjerg P. L., Jensen D. L., Christensen J.B., Baun A., Albrechtsen H.-J., Heron G. 2001. Biogeochemistry of landfill leachate plumes. Applied Geochemistry. 16(7-8). 659-718. https://doi.org/10.1016/S0883-2927(00)00082-2

2. Deng Y., Englehardt J.D. 2006. Treatment of landfill leachate by the Fenton process. Water Research. 40(20). 3683-3694. https://doi.org/10.1016/j. watres.2006.08.009

3. Dmitriev M.T., Kaznina N.I., Pinigina I.A. (1989). Sanitary and chemical analysis of pollutants in the environment. Handbook. Moscow: Chemistry.

4. Fytanidis D.K., Voudrias E.A. 2014. Numerical simulation of landfill aeration using computational fluid dynamics. Waste Management. 34 (4). 804-816. https://doi.org/10.1016/j.wasman.2014.01.008

5. Haydin A.M., Dyakiv V.O., Pohrebennyk V.D., Pashchuk A.V. 2013. Chemical content of the leachate of the Lviv solid waste landfill. Lviv. Geography. $10,43-49$.

6. HeaveyM.2003. Low-cost treatment oflandfill leachate using peat. Waste Management. 23 (5). 447-454. https://doi.org/10.1016/S0956-053X(03)00064-3

7. Hlobenko V.A. 2016. Organization of search and rescue and other urgent activities for the consequences of emergency at the solid waste landfill. Modern status of civil protection of Ukraine: perspectives and ways to European integration: materials of 18th Ukrainian scientific and practical conference of rescuers. (pp. 343-344). Kyiv: The State Emergency of Ukraine.

8. Kulikowska D., Klimiuk E. 2008. The effect of landfill age on municipal leachate composition. Bioresource Technology. 99(13). 5981-5985. https://doi. org/10.1016/j.biortech.2007.10.015

9. LGD 211.1.0.009-1994. Hydrosphere. Sampling for determination of content and properties of waste and technical water.

10. LGD 211.1.4.023-1995. Method of photometric determination of nitrite-ions with the Griess reagent in surface and purified wastewaters.

11. LGD 211.1.4.027-1995. Method of photometric determination of ammonium-ions with the Nessler reagent in wastewaters.

12. LGD 211.1.4.027-1995. Method of photometric determination of nitrates with salicylic acid in surface and biologically purified waters.

13. LGD 211.1.4.034-1995. Method of photometric determination of total iron in surface and wastewaters. 
14. LGD 211.1.4.039-1994. Method of gravimetrical determination of suspended matters in natural and wastewaters.

15. LGD 211.1.4.042-1995. Method of gravimetrical determination of dry residue (soluble substances) in natural and wastewaters.

16. Lurie Y. 1984. Analytical chemistry of industrial wastewater. Moscow: Chemistry.

17. Malovanyy M., Zhuk V., Sliusar V., Sereda A. 2018. Two stage treatment of solid waste leachates in aerated lagoons and at municipal wastewater treatment plants. Eastern-European Journal of Enterprise Technologies. 1(10). 23-30. https://doi.org/10.1558 7/1729-4061.2018.122425

18. Mor S., Ravindra K., Dahiya R. P., Chandra A. 2006. Leachate Characterization and Assessment of Groundwater Pollution Near Municipal Solid Waste Landfill Site. Environmental Monitoring and Assessment. 118 (1-3). 435-456. https://doi. org/10.1007/s10661-006-1505-7

19. Popovych V., Stepova K., Prydatko O. 2018. Environmental hazard of Novoyavorivsk municipal landfill. MATEC Web of Conferences 247, 00025. FESE 2018. https://doi.org/10.1051/ matecconf/201824700025

20. Renou S., Givaudan J. G., Poulain S., Dirassouyan F., Moulin P. 2008. Landfill leachate treatment: Review and opportunity. Journal of Hazardous Materials. 150(3). 468-493. https://doi.org/10.1016/j. jhazmat.2007.09.077

21. Suchecka T., Lisowski W., Czykwin R., Piatkiewicz
W. 2006. Landfill leachate: water recovery in Poland. Filtration \& Separation. 43 (5). 34-36, 38. https://doi.org/10.1016/S0015-1882(06)70891-6

22. Tulaydan Y., Malovanyy M., Kochubei V., Sakalova H. 2017. Treatment of high-strength wastewater from ammonium and phosphate ions with the obtaining of struvite // Chemistry \& Chemical Technology. 11 (4). 463-468. https://doi.org/10.23939/ chcht11.04.463

23. Uygur A., Kargi F. 2004. Biological nutrient removal from pre-treated landfill leachate in a sequencing batch reactor. Journal of Environmental Management. 71(1), 9-14. https://doi.org/10.1016/j. jenvman.2004.01.002

24. Vodyanitskii Yu. N. 2016. Biochemical processes in soil and groundwater contaminated by leachates from municipal landfills (Mini review). Annals of Agrarian Science. 14(3), 249-256. https://doi. org/10.1016/j.aasci.2016.07.009

25. Voloshyn P. 2012. Analysis of the influence of the Lviv landfill on the environment. Lviv university herald. Geological Series. 26, 139-147.

26. WDS № 081/12-0116-2003. Method of measurement of mass fraction of oil products with gravimetrical method.

27. Xiaoli C., Shimaoka T., Xianyan C., Qiang G., Youcai Z. 2007. Characteristics and mobility of heavy metals in an MSW landfill: Implications in risk assessment and reclamation. Journal of Hazardous Materials. 144(1-2), 485-491. https://doi. org/10.1016/j.jhazmat.2006.10.056 